Itinera Spiritualia

$\mathrm{X} \cdot 2017 \cdot 55-70$

JeRZY WIEStAW GOGOLA OCD

\title{
THE INFLUENCE OF ST JOHN OF THE CROSS ON THE SPIRITUAL PATH OF ST TERESA BENEDICTA OF THE CROSS (EDITH STEIN)
}

Every man has his own unique path to becoming united with God, but his development cannot proceed naturally, or indeed at all, without others. In man's natural development the influence of his closest relatives in the first years of his life is so great that it becomes, in most cases, the determining factor in his formation for the rest of his life. This influence extends even into the supernatural areas of life. As he matures, it diminishes, until, in his teenage years, the adolescent usually clashes with his parents; this comes as a result of his discovery and appreciation, at least to a certain degree, of his own unique and autonomous personality.

Let us now consider Edith Stein. We can speak of the influence of St John of the Cross on her spiritual path only in relation to the last period of her life, namely the time when she was already a Carmelite. Still, we cannot ignore the first thirty years of Edith's life if we want to understand why, as this article will attempt to show, St John of the Cross was so important to her. It is in this very period that we find the reason why Edith chose him later as her spiritual guide. It seems that this reason was their spiritual kinship, which was related not only to their common Carmelite vocation.

The structure of this paper rests on three assumptions: the similarity on the natural level, the similarity on the spiritual level, and St John's spiritual guidance. 


\section{Historical LEVEL SIMILARITY: LIFE PATH}

Here are a few significant similarities:

Loss of the father. Both John of the Cross and Edith lost their fathers early in life which undoubtedly influenced their human and religious upbringing.

Science. Their studies were in similar fields, e.g. they both studied St Thomas and the scholastic theology. Exploring the theological thought of the same masters certainly brings people closer to one another in their way of thinking and their perception of reality. Edith had an additional advantage over John of the Cross: she could study his own works and enter, as few could, into his inner world; we can make such a supposition, considering her doctoral thesis on empathy, as well as her last work, The Science of the Cross (Scientia Crucis), which was undoubtedly also autobiographical.

Serving the sick in a hospital. Undertaking this kind of work points to their sensitivity to the needs of others. John of the Cross worked at a hospital as a boy, Edith as an adolescent. Both were volunteers. It is worth noticing that Edith, working as a nurse when she was still an atheist, was motivated by the love for her homeland and her countrymen who needed help.

Love for their mothers and siblings. John's and Edith's love for their mothers is understandable first of all because they both hardly knew their fathers. Their mothers were to them both mother and father figures. It may be worth noting when we ponder their love for God. They did not know the love of a human father. They prayed to God the Father perceiving Him through the prism of motherly love. This is not insignificant in the understanding of the love of God. Other aspects that need to be brought to the foreground are the personality, the ingenuity, and the courage of their mothers.

John's mother had to move several times and she was not discouraged when the relatives of her deceased husband repulsed her and simply refused to help her. Edith's mother had more children to take care of and an enterprise on the brink of failing. Her financial situation was undoubtedly better, but she also needed much courage to think of the future.

Edith's love for her mother was great. We can grasp its extent when we realize that it was for her mother's sake, although also of course after consulting her confessor, that Edith postponed her entrance into Carmel. But her love for Christ was greater.

As far as siblings are concerned, John's love for his brother Francis is abundantly proved by many testimonies from the period, including the testimony of Francis himself. ${ }^{1}$

1 Bóg mówi pośród nocy, ed. Cz. Gil, Kraków, 1991, p. 341. 
Edith, just like John the youngest in her family, was the seventh child of the Steins. Much could be said about the joys and sorrows in the relationships with her siblings, but let us only mention the bond she had with her sister Rose. In January 1942, Teresa Benedicta realized that she could not remain at Echt without endangering the lives of the other sisters at the convent. She wanted to relocate officially to Switzerland, to the only Discalced Carmelite convent there. Unfortunately, the convent offered only one place and Edith would not go without her sister Rose. ${ }^{2}$ From the human point of view, the probability that she could have saved her own life is very high. Yet rejecting this possibility seemed to her a most obvious decision; there was simply no other option in this situation. From the last journey of Edith, which she made together with Rose, no words spoken by the latter have reached us. Still, it is natural that they must have talked about the possibility of death because it was also on Rose's behalf that Edith, taking her sister by the arm, pronounced the words, "Let us go and offer a sacrifice for our people." ${ }^{3}$ Edith probably experienced Rose's death, sharing in her sister's suffering until the last moment.

Own death. Both John and Edith went to meet God with full awareness and great calm.

Teresa of Avila. She played a crucial role at one point in their respective lives. The providential meeting of John and Teresa of Jesus took place in 1567. It was as providential as the encounter a couple of centuries later, when Edith and Teresa "met" by means of Teresa's book entitled Life. Thanks to Teresa, both John and Edith glimpsed the truth which they were looking for. Meeting Teresa was, for both of them, just the beginning of the path which they were to tread. Those who search must continue to walk their way, and this is what they did.

\section{SPIRITUAL Similarity}

Another thing John and Edith had in common was their passionate search: the same path of Christ's Cross and the same wisdom gained on that path, the wisdom of the Cross. Edith passionately searched for Truth, and John - for Love. That love, from the beginning, was personal: it was the love of Christ the Beloved, the One whose love wounds the soul. The truth which Edith searched for turned out to be, some time later, the same person: Jesus Christ. At that moment, for her, Truth and Love met. In other words, Edith, while looking for Truth, found Love.

Teresia A Matre Dei, Edith Stein. En busca de Dios, $5^{\text {th }}$ edition, Navarra, 1987, p. 279.

Ibid., p. 288. 


\subsection{The passionate search for truth}

Edith spoke of her spiritual way essentially in terms of the quest for truth. She regarded truth as the highest value. ${ }^{4}$ Congregatio pro Causis Sanctorum (Congregation for the Causes of Saints) in its documents ${ }^{5}$ speaks even of Edith's love for truth. ${ }^{6}$

Prompted by her longing for truth, she found her way to the University of Göttingen where she wanted to pursue it by deepening her knowledge. It is there that she met the people who in a sense opened before her the path to Christianity.

In her testimony, one of the Carmelites of Cologne quoted what Edith had once said during recreation:

The University of Breisgau had these words from the Gospel displayed in large letters: "Truth will set you free." Oh, when you think what is being taught there as truth, you must be greatly saddened! This knowledge, so highly praised, will never make people free. ${ }^{7}$

Truth was always foremost in her mind, whether in the field of philosophy or theology. ${ }^{8}$ She believed that only truth was worthy of faith.

The point of reference and the criterion for examining truth was its indelibility. Philosophy, as Edith was convinced, should also be in the service of truth; she accepted philosophy only as far as it really served truth. In her work Finite and Eternal Being she wrote that the noblest task of philosophy was to prepare the path for faith. ${ }^{\text {? }}$

Edith confessed truth without regard for any troublesome consequences. One example is the political election day on April 10, 1938. On that occasion she declared that no Christian or religious could support a regime which is hostile toward God. She was summoned to a German office where she answered the salute of a German clerk with the traditional greeting "May Jesus Christ be praised." Later, taking to the prioress of the Carmel in Echt, she admitted that she had felt an inner impulse to react in this way, imprudent from the human

4 J.M. Garcia Rojo, Juan de la Cruz y Edith Stein. Caminos convergentes, in Revista de Espiritualidad 50 (1991), pp. 419-442.

5 Congregatio pro Causis Sanctorum, P. N. 1182, Teresiae Benedictae a Cruce. Positio super martyrio et super virtutibus, Roma, 1986.

6 Ibid., p. 69.

7 Ibid., p. 74 , no. 119.

8 Cf. ibid.

9 Cf. ibid., no. 120. 
point of view, because she realized that it was not at all about politics but about the eternal battle between Christ and Lucifer. ${ }^{10}$

During the first period of Edith's life, truth in her heart took the place which belonged to faith and love. There was a time in her life when, as her first biographer noted, she "could not believe in the existence of God."11 As a fully-fledged young woman, she declared herself an atheist. As such, she could do without God, but she could not do without truth. ${ }^{12}$

In love with truth, she sought it in phenomenology. The phenomenological method was a good start, but it did not lead to final solutions or to the discovery of the ultimate truth. The Catholic philosopher Scheler opened before her the world which goes beyond that of philosophy. ${ }^{13}$ "It was my first contact with a world until then completely unknown to me. But it did not lead me to faith. Still, it led me into the sphere of certain phenomena which I had to acknowledge."14 In 1917, the philosopher Reinach died in the war. In his wife, for the first time in her life, Edith saw the victory of the Cross over death. It was then that Edith's unbelief fell apart and Christ shone forth in the mystery of the Cross. ${ }^{15}$

This was my first encounter with the Cross and the divine power it imparts to those who bear it. It was the moment when my unbelief collapsed and Christ began to shine His light on me, Christ in the mystery of the Cross. ${ }^{16}$

Finally, she found the ultimate truth at the home of Jadwiga Konrad Martius, where all night long she was reading St Teresa's Life; closing the book, she said to herself: "This is truth." It was not, however, the end of her path; in fact, it was the beginning of a new one. After years of searching, she discovered that the ultimate Truth is to be found in the Church, not at the university.

10 Cf. ibid.

11 Quoted in T. R. Posselt, Una gran mujer de nuestro siglo, San Sebastian, 1953, p. 22.

12 Cf. J.M. Garcia Rojo, Juan de la Cruz y Edith Stein, p. 420.

13 Cf. F. Malax, Beata Edith Stein, Victoria: Ediciones del Carmen, p. 10.

14 Congregatio pro Causis Sanctorum, Teresiae Benedictae a Cruce, p. 70, no. 115.

15 J.M. Garcia Rojo, Juan de la Cruz y Edith Stein, p. 423.

16 Wiedza Krzyża. Studium o św. Janie od Krzyża, in Teresa BenedyKTa od Krzyża, Świattość w ciemności. Wybór pism duchowych, vol. 1, Kraków, 1977, p. 201. The English translation of all quotations from Edith Stein's works is by the author of the article. 


\subsection{The passionate search for love}

John of the Cross is often regarded as a man of just one ideal, i.e. of the union with God. He was a theologian, a man of great artistic sensitivity, but most of all a man of God.

In fact, John himself admitted openly that his entire spiritual path was marked by the powerful longing for the union with Christ. As we know, his writings are autobiographical, although he never mentions it himself. The Spiritual Canticle describes his own spiritual path, the path leading up to the full union with God; it documents the path of a soul on fire with love who overcomes all obstacles, including herself, and reaches the much desired goal.

John is an unwearied seeker of Love. When he comments on a verse of his Spiritual Canticle, "Seeking my love," (stanza 3) he warns that in order to meet God it is not enough to speak and pray, one must also act. Seeking God is difficult and costly. The example John gives is the bride of the Song of Songs who did not find rest until she found the one whom her soul loved.

He claims that the first condition to meet God is to leave oneself: "the soul [must depart] from the house of her own will and the bed of her own satisfaction." (Spiritual Canticle 3.3) But even that is not enough. It is also necessary to have a heart "strong and free" (Spiritual Canticle 3.5) which will not stop on the way and gather flowers, and which will not fear wild beasts. Who truly seeks the Beloved must be detached, strong, and virtuous.

The entire spiritual life of John of the Cross was animated and moved by love which became his true passion. Love meant to John what truth meant to Edith: wellbeing of the soul and remedy for all evil. A soul wounded by love goes out to look for her Beloved. This is the right attitude of man; we were created to love. (Spiritual Canticle 29.3) Love is man's vocation. This is why we can never fathom the truth about man if we leave God aside. God Himself teaches us who we really are.

It needs to be added that this search lasts a lifetime. Therefore, the main error committed by the believer walking this path is impatience and the wish to skip over some stages of it, which must be patiently trodden ${ }^{17}$. In fact, the main protagonist of this story is not man but God. God guides man out of his house and draws to Himself, setting his heart on fire with love. The force of God's love is as strong as gravity to a falling stone. (Spiritual Canticle 12.1) Just as the stone has no other option but to fall down, the man who wants to be united with his Beloved can do nothing else except to let himself be loved. Unfortunately, what is simple in theory is not so easy in practice.

17 J.M. Garcia Rojo, Juan de la Cruz y Edith Stein, p. 428. 
John expresses his regret over this fact in the Prologue of his Ascent of Mount Carmel: how some people do not let God guide them. They are like children who do not allow their loving mother to carry them; instead, they try to go their own way, thwarting her efforts.

A certain pattern characteristic in John of the Cross can also be noticed in the case of Edith: people who seek are also sought. (Their search is in itself the consequence of having met someone who stirred in them the desire to seek). The truth never too often repeated is that on the spiritual path God always takes the initiative. He is always the one who comes out to meet man, much earlier than man can even decide to take the first step toward Him. "In the first place it should be known that if anyone is seeking God, the Beloved is seeking that person much more" (Living Flame of Love 3.28.) At the beginning of the Spiritual Canticle John says that this initiative of God toward man is eternal, preceding even his birth. Man is born already with a long history of God's love for him.

Who seeks truth or love, finds much more than he imagined: he finds God.

\subsection{The way and the wisdom of Christ's Cross}

It is known that the Cross marked the life of St John from his very childhood; perhaps this helped him understand very quickly the Love of God, which descends to man in Christ Crucified, and link his fate with Christ's fate. He consciously changed his religious name from John "of St Matthew" to John "of the Cross." In this way, he wanted to express the peculiarity of his spiritual path.

This is also how Edith perceived it when she wrote The Science of the Cross. As Immakulata Adamska writes, "the third part of the book, entitled The Imitation of the Cross, which sketches out her thought... is partly St John of the Cross' biography, written from the point of view of his love toward Christ Crucified. Edith Stein wanted to show the fruit of the Saint's teaching on the basis of his own life and to stress how his life was aligned with his work and his doctrine." ${ }^{18}$ In other words, she wanted to show that the Mystical Doctor shares what he experienced and leads along the path which he trod himself, which he also knows to be the shortest and leading infallibly to his goal.

The Cross was present also in Edith's life. It would be hard to describe its colors. Let us just mention two aspects of it: first, her great love for her mother, who was agonized when Edith converted to Catholicism, and second, being part of the Jewish people. It is known that man suffers most in his relationships to other people. Edith experienced the weight of her cross gradually, as its heaviness moved into the depths of her soul.

18 J.I. Adamska, Od thumacza, in Teresa BenedyKTa od Krzyża, Świattość w ciemności, vol. 2, p. 9. 
In 1933, she participated in the Holy Hour led by the canon Wüsten. In this context, she offered the following testimony:

I talked to the Savior and I told Him that I knew it was His Cross that was now put upon the Jewish people. It is not generally understood but those who do understand must be ready to carry it on behalf of all. I want to do it; I only want Him to show me how. When the service was over, I had the inner conviction that my prayer was heard. But I didn't yet know what this carrying of the cross was going to mean in practice. ${ }^{19}$

Edith had the ability to connect the cross of her family relationships and the cross of belonging to the Jewish people with the Cross of Christ. In the context of the concentration camp and all that it stands for, she is a clear example of how love coming from Christ Crucified is stronger than the greatest suffering and the greatest human wickedness.

In the camps which she passed through before she died, Edith showed remarkable serenity, as we know from the witness accounts. ${ }^{20}$ It must have been due, at least in part, to her contact with the mysticism of St John of the Cross, whose fruit was Edith's last work entitled The Science of the Cross. In this book, recounting the experience of John, which became the bearer of his mystical doctrine, she describes at the same time her own path. "The path to full union is the path of faith, and the path of faith is a night path." ${ }^{21}$ Night and the Cross are inseparable.

Edith interprets entering into the night as taking up the $\mathrm{cross}^{22}$ since the entire path leading through the night is the evangelical path. "Every one of you who does not renounce all his possessions (also the things possessed through desires) cannot be my disciple." (Luke 14:33) Embracing the hardship and suffering brought on by renunciation is taking up one's own cross. ${ }^{23}$

The active entrance into the dark night of the senses is synonymous with embracing our cross and bearing it patiently. But we do not die just carrying the cross... We can give ourselves up for crucifixion, but we cannot crucify ourselves. This is why all that the active night initiates must be completed in the passive night. ${ }^{24}$

19 Wiedza Krzyża. Studium o św. Janie od Krzyża, vol. 1, p. 220.

20 J.M. Garcia Rojo, Juan de la Cruz y Edith Stein, p. 437.

21 Teresa Benedykta od KrzyŻa, Świattość w ciemności, vol. 1, p. 55.

22 Ibid., p. 56.

23 Cf. ibid., p. 57

24 Ibid., p. 59. 
The passive night is interpreted by Edith as crucifixion..$^{25}$

It is no exaggeration to say that suffering in this state is crucifixion: it nails one down with the impossibility to use natural forces. Dryness is coupled with the torment brought on by the fear that we are not walking the true path. ${ }^{26}$

The way of the cross and death on the cross consist in the emptying of spiritual faculties. ${ }^{27}$ "Whoever wishes to come after me must deny himself, take up his cross, and follow me" (Mark 8:34). Edith, following St John of the Cross, applies this doctrine to the process of inner transformation. She quotes a long passage from Ascent to Mount Carmel which summarizes this teaching:

Christ is our Way. All we need to do is understand how to follow His lead. (Here she begins to quote St John of the Cross.) "In the first place, it is certain that He died as to sense, spiritually, in His life, besides dying naturally, at His death. For, as He said, He had not in His life where to lay His head, and at His death this was even truer.

"In the second place, it is certain that, at the moment of His death, $\mathrm{He}$ was likewise annihilated in His soul, and was deprived of any relief and consolation, since His Father left Him in the most intense aridity, according to the lower part of His nature. Wherefore He had perforce to cry out, saying: 'My God! My God! Why hast Thou forsaken Me?' (Matthew 27:46) This was the greatest desolation, with respect to sense, that He had suffered in His life. And thus He wrought herein the greatest work that He had ever wrought, whether in miracles or in mighty works, during the whole of His li$\mathrm{fe}$, either upon earth or in Heaven, which was the reconciliation and union of mankind, through grace, with God. (2 Ascent of Mount Carmel 7:10-11)

"He who for Christ's sake renounces all that his will can desire and enjoy, and chooses that which is most like to the Cross, the same shall gain it. (2 Ascent of Mount Carmel 7:6)

"And when at last he is reduced to nothing, which will be the greatest extreme of humility, spiritual union will be wrought between the soul and God, which in this life is the greatest and the highest state attainable. This consists not, then, in refreshment and in consolations and spiritual feelings,

25 Ibid.

26 Ibid., p. 61.

27 Ibid., p. 69. 
but in a living death of the Cross, both as to sense and as to spirit - that is, both inwardly and outwardly." (2 Ascent of Mount Carmel 7:11) ${ }^{28}$

This entire teaching speaks of the passive purification of the senses and can be found in the second part of The Science of the Cross. Afterwards Edith, in keeping with the logic of purification as found in St John of the Cross, moves on to discuss the passive night of the spirit, ${ }^{29}$ entitling this part of her work "Death and Resurrection." On the mystical path, there comes a "moment" (which may last several years) when the believer sinks completely in darkness and emptiness. He is left with no foothold except faith. And faith puts Christ before his eyes: poor, humiliated, crucified, "abandoned" on the Cross by God. "In His poverty and abandonment man finds himself. Dryness, repugnance and torment are the 'purely spiritual cross' which (man) is to take up." ${ }^{30}$

He takes up this cross out of love which God kindles in him more and more powerfully. The power of infused contemplation can be likened to that of fire. "Eternal love is a devouring fire to all transient things." ${ }^{11}$ Edith goes on to say that the experience of a believer on the path of the night can be likened to what happens in the mystery of Christ's death: "The depth of his soul (the soul of Jesus) was ceaselessly consumed by the expiatory fire of the sufferings of His entire human life, which came to a climax in the Garden of Olives and on the Cross." 32

Edith concludes the meditation in this part of The Science of the Cross by linking the mystery of Jesus Crucified with the figure of the believer undergoing the purification of the passive night of the spirit:

In the Passion and death of Christ fire consumed our sins. When we believe it, when we embrace the whole Christ with the devotion that comes from faith, we choose the path of following Him and we actually walk it; then $\mathrm{He}$ will lead us "through His suffering and Cross to the glorious resurrection." This is what one experiences in contemplation: passing through the expiatory fire to the happy union in love. And this explains the double character of contemplation: it is death and it is resurrection. After the dark night the living flame of love shines forth. ${ }^{33}$

\footnotetext{
Ibid. p. 70 and 71

Ibid., p. $123 \mathrm{ff}$.

Ibid., p. 123.

Ibid., p. 182.

Ibid., p. 184.

Ibid.
} 
The last point in this second part of The Science of the Cross is "The Glory of the Resurrection" in which Edith comments on The Living Flame of Love. ${ }^{34}$ John's blood brother's testimony tells us that toward the end of John's life, when he was the superior in Segovia, he clearly embraced the wisdom of the cross. In his earthly life, he wanted only "to suffer, and to be despised" for Christ's sake ${ }^{35}$.

Edith's superiors officially wanted her to write the commentary on John to celebrate the $400^{\text {th }}$ anniversary of his birth. It is, however, very probable, that this work was meant to keep her mind off the unfolding tragic events ${ }^{36}$.

\subsection{Scientia Crucis}

Walking the way of Christ, John and Edith understood that the union with God to which we have the honor to be invited can be reached only with a cross. Through the cross the love between the Beloved and the soul is completed. Crucifixion in spiritual life means death to the life on the level of pure senses.

Without one's cross, one cannot imitate Christ and enter into His glory. The cross, just as the night of faith, purifies man and leads him to put his trust exclusively in God. To trust God means to allow for the work of the Holy Spirit who in an astonishing manner transforms man into a flame of love (configures human love to His own Divine love.)

This way, the science of the Cross, which has nothing to do with any form of masochism, becomes a song about the dignity of man, whom God allowed to participate in His own Divine life. ${ }^{37}$

The science of the Cross, meditated by Edith in writing, was to become her first-hand experience. Her life was to turn into a way of the cross that she would tread with great dignity, setting an example for others, thanks to her familiarity with the science of the Cross.

A month after the events of the "Crystal Night," she wrote:

I was allowed a religious name of my own choice. In the word cross I saw the symbol of the destination of God's people... Today I certainly grasp a much deeper sense of what it means to be espoused to the Lord under the sign of the Cross. It cannot ever be fully fathomed, for it is a mystery.

\footnotetext{
34 Ibid., p. $184 f f$.

35 Bóg mówi pośród nocy, p. 341.

36 Cf. J.M. Garcia Rojo, Juan de la Cruz y Edith Stein, p. 438.

37 Cf. ibid., p. 439.
} 
From Echt, she wrote to the same person three weeks later: "There is no human consolation but the one who gives the cross knows how to make its burden sweet and light." 38

Edith tasted this loving knowledge of which she wrote and which she had acquired in her life. This science of the Cross, which is, after all, a gentle love reciprocated to the Beloved Crucified, permeated her entire life. When the turn of events posed an immediate threat to her life, she wrote from the convent at Echt, in December of 1941: "Scientiam crucis is acquired only when one fully experiences the Cross. I have always been convinced of this: Ave Crux, Spes unica." 39

\section{John of the Cross as a guide on Edith Stein's spiritual path}

The first meeting of Teresa Benedicta of the Cross with the great Teresa of Avila took place in the summer of 1921 and was the crowning of her quest for Truth, and at the same time the beginning of a new path in the company of Christ. There are various hypotheses along the lines that Edith owes her conversion to Catholicism to Teresa and her entrance into Carmel to John..$^{40}$ It is not unlikely that he indeed played a role in her decision to embrace Carmelite life. Still, there is no solid evidence to back up this claim.

It would be hard to speak of some meaningful "meeting" of Edith and John before she entered Carmel. We can only say that she did know him before entering religious life and considered him a great saint and mystic. The earliest proof of this can be found in her letter of 1927 to Roman Ingarden ${ }^{41}$ (written six years before she entered Carmel.) Sister Carla Bettinelli claims that one of the first encounters of Edith with John of the Cross took place in 1926, when John was proclaimed Doctor of the Church. ${ }^{42}$ Edith was in Speyer at the time, studying St Thomas, and she participated beyond doubt in important events of the Church. By then she probably already knew John's works. It is clear from the letter written to Ingarden only two months later (Bergzabern, 1 January 1928) that she

\footnotetext{
Cf. ibid., note 42 .

Teresa Benedykta od Krzyża, Swiattość w ciemności, vol. 1, p. 280.

J.M. Garcia Rojo, Juan de la Cruz y Edith Stein, pp. 430-431.

41 Cf. E. Stein, Briefe an Roman Ingarden 1917-1938, Freiburg-Basel, 1991. "Where we lack our own experience, we need to refer to the testimonies of homines religiosi which are abundant. In my opinion, the testimonies of the Spanish mystics Teresa and John of the Cross are the most expressive." (Spór o prawde istnienia. Listy Edyty Stein do Romana Ingardena, Kraków-Warszawa, 1994, Letter 116; cf. also Letter 119).

42 C. Bettinelur, Edith Stein legge l'Io di Giovanni, in Quaderni Carmelitani 9 (1992), p. 167.
} 
had read the Mystical Doctor's writings ${ }^{43}$ and even that his mystical experience had an important place in her spiritual life. ${ }^{44}$ St Thomas undoubtedly prepared Edith in some measure for the guidance of John of the Cross, for the study of the Angelic Doctor brought a new quality into her quest for God. She began to understand that faith was a path to truth. Faith discovers what the mind is not able to comprehend. And what the mind is not able to comprehend is love, because it transcends all philosophy. ${ }^{45}$

Reading St Thomas led Edith to a more theological perception of reality. Even at the outset of her spiritual life we see her being guided by St John of the Cross. Before her retreat at taking the habit, for her meditative reading she chose John of the Cross. A year later, when time came for her first vows, she did the same.

The religious name received at entering Carmel expresses the truth about Edith's spiritual path. Teresa was the one who brought about her discovery of Christ. Benedicta came from the Benedictine monastery at Beuron, where she sometimes spent Easter and lived some unforgettable moments ${ }^{46}$; its abbot Walzer ${ }^{47}$ was her spiritual director. The Cross was the place of her encounter with John of the Cross.

At a certain time in her life, Edith's "master" was Husserl. Later, John of the Cross took his place. In what way did Edith perceive the guidance of John of the Cross? A wise guide walks ahead of his charges, as the name itself indicates. If the path leads through darkness, he takes them by the hand, but he does not carry them. Only infants are carried. The image of a parent carrying an infant in his arms was used by St Thérèse of Lisieux as a description of God, never of man. When Edith encountered John of the Cross on her spiritual path, she was a woman of uncommon intelligence, mentally, emotionally, and spiritually mature. She did not need a guide to ensure her psychological wellbeing but to follow her own unique vocation. A guide provides assistance, but does not take the steps for those whom he leads. This is why John of the Cross was to Edith

43 "I would only advise you, as I mentioned before, to rely on the works of mystics and great saints of the Church: on the story of the life of St Teresa... and on the writings of St John of the Cross" (Spór o prawde istnienia, p. 199).

44 Cf. Spór o prawde istnienia, Letter 119

45 Cf. J.M. Garcia Rojo, Juan de la Cruz y Edith Stein, p. 429.

46 "On Thursday in the Passion Week I went to Beuron. Since 1928 I've passed every Holy Week and Easter there, at the same time making my retreat" (TERESA BenfDYKTA OD KRZYŻA, Świattość w ciemności, vol. 1, p. 219).

47 Congregatio pro Causis Sanctorum, Teresiae Benedictae a Cruce, p. 10-11. "Since I found in Beuron my monastic shelter, I was allowed to see in Abbot Raphael 'my superior' and to ask for his decision in all important matters" (TERESA BENEDYKTA OD KRZYŻA, Świattość w ciemności, vol. 1, p. 219). 
a "master" who did not drag her along wherever he went, but instead led her by the hand on her own path.

In what does his guidance consist? As it is widely known, John of the Cross is the guide on the path which leads through the night to the top of the mystical Mount Carmel, i.e. to the transforming union with God through love. As Luigi Boriello notices ${ }^{48}$, Edith walked the very path that John of the Cross had trodden before, and she acquired the same knowledge, the science of the Cross, or even the wisdom of the Cross. This wisdom is focused on the mystery of Christ's Cross and His Resurrection; in other words, on God's unlimited love for man experienced in one's own life.

\section{CONCLUSION}

The presented similarity, or rather kinship between these two great figures of Christianity and Carmel seems to suggest caution in outlining the influence of John of the Cross on the spiritual path of Edith Stein. They are certainly very similar, but that similarity is the result of their similarity to Christ in His mystery of the Cross. This similarity is the work of the Holy Spirit. It would be a risky venture to try and estimate how much and what exactly Edith owes John. Still, on the basis of hard facts, we can say that St John of the Cross is considered not only the spiritual guide for the entire Carmel but also as its Father. Carmelites, by virtue of their vocation, should walk the same path as St John of the Cross; any personal need for his help is already inherent in that vocational choice.

One illustration of this is the following event. In 1939, Edith was asked to prepare a brief reflection for the feast of the Exaltation of the Holy Cross; it was usually delivered by the prioress herself. Edith took this occasion to show the Carmelite vocation in the light of Christ's Cross. In her meditation, the ultimate sense of the Cross is to liberate the world from the damage of sin and from death. In order for this to happen, the Carmelite nun should let herself be nailed to the Cross together with Christ. The nails are the three vows. On the Cross, the Christian, together with Christ, undertakes the expiation for the sin of the world. The Cross is the only hope of salvation for the world. ${ }^{49}$ The Beloved for the Carmelite, and for every soul, is the Lamb of God, offered in sacrifice for the sins of the world. If she is to follow Him all the way to glory, she must walk the same path as He did.

48 L. Boriello, Giovanni della Croce e Edith Stein, in Rivista di ascetica e mistica 16 (1993), p. 69.

49 Cf. J.M. Garcia Rojo, Juan de la Cruz y Edith Stein, p. 434. 
As indicated above, we find the very same teaching in the works of St John of the Cross (2 Ascent of Mount Carmel 7:8).

It is clear, then, that the influence of John of the Cross on Edith Stein, a Discalced Carmelite, was very great already on the basis of the vocation they shared; additionally, we have shown that it was peculiar also for other reasons. 


\begin{abstract}
JERZY WiestaW Gogola OCD

The Influence of St John of the Cross

on the Spiritual Path of St Teresa Benedicta of the Cross (Edith Stein)
\end{abstract}

The article presents the claim that the basis of Edith Stein's perfect understanding of the mystical doctrine of St John of the Cross is the similarity between these two saints, both in the historical and in the spiritual sense. Spiritual direction finds very good ground when there is perfect understanding between the spiritual director and the directee, and when they participate in the same reality.

To justify this claim, the article discusses three points: the similarity of the life path of both saints on the historical level; the spiritual similarity between them; and John of the Cross as Edith Stein's guide on her spiritual path. We can find many analogies in their respective lives: their studies, their love of own family, St Teresa of Jesus, their death. Also, although in her last work entitled Scientia Crucis Edith explains the spiritual path of St John of the Cross, the book can certainly be considered autobiographical. They both passionately sought truth and love; they both accepted being nailed to Christ's Cross; they both attained the scientia Crucis, being united with the Crucified Lord, whether through mystical death or a death that was at the same time mystical and physical.

One more factor to be considered is the Carmelite vocation. John of the Cross is the spiritual father of the Carmel and as such naturally becomes a spiritual guide to all Carmelites on their way to union with God. Moreover, Edith Stein had many personal reasons for embracing his guidance.

Słowa klucze: św. Jan od Krzyża, Edyta Stein, prawda, miłość, cierpienie Keywords: St John of the Cross, Edith Stein, truth, love, suffering 